\title{
Laxitextines A and B, Cyathane Xylosides from the Tropical Fungus
}

\section{Laxitextum incrustatum}

Cynthia M. Mudalungu, ${ }^{\dagger}$ Christian Richter, ${ }^{\ddagger \S}$ Kathrin Wittstein, ${ }^{\ddagger \S}$ Muna Ali Abdalla, ${ }^{\dagger}$ Josphat C. Matasyoh, ${ }^{\perp}$ Marc Stadler, ${ }^{* \ddagger \S}$ Roderich D. Süssmuth ${ }^{* \dagger}$

†Institut für Chemie, Technische Universität Berlin, Strasse des 17. Juni 124, 10623 Berlin, Germany

${ }^{\dagger}$ Department of Microbial Drugs, Braunschweig, Helmholtz Centre for Infection Research GmbH, Inhoffenstraße 7, 38124 Braunschweig, Germany

${ }^{\S}$ German Centre for Infection Research, partner site Hannover-Braunschweig, Inhoffenstraße 7, 38124 Braunschweig, Germany

${ }^{\perp}$ Department of Chemistry, Egerton University, P.O. Box 536, Egerton, Kenya 


\section{Supporting Information}

Figure S1: Macro and micro morphologic features of Laxitextum incrustatum

Figure S2: Antimicrobial activity against Staphylococcus aureus DSM 346 and MRSA (DSM 1182)

Figure S3: HPLC profile of the methanol crude extract

Figure S4-S5: Total Ion concentration and HRMS for laxitextine A (1)

Figure S6-S11: $1 \mathrm{D}$ and $2 \mathrm{D}$ NMR $\left(\mathrm{CDCl}_{3}\right)$ spectra for laxitextine A (1)

Figure S12-S13: Total Ion Chromatogram and HRMS for laxitextine B (2)

Figure S14-S20: $1 \mathrm{D}$ and $2 \mathrm{D}$ NMR $\left(\mathrm{CD}_{3} \mathrm{OD}\right)$ spectra for laxitextine B (2)

Figure S21-S22: IR spectra of laxitextines A (1) and B (2) 


\section{Characteristics of the Producing Organism}

The culture of Laxitextum incrustatum was obtained from a basidiospore print of the collected fruiting body under sterile conditions and cultivated on YMG agar plates with penicillin and streptomycin to avoid bacterial growth. It showed the salient characteristics of a basidiomycete, i.e., hyphae with clamp connections, and is therefore presumably a dikaryon. The voucher specimen is deposited at the Egerton University, Kenya under the collection number STMA 14285. The 5.8S region, the internal transcribed spacer 2 (ITS2) and parts of the large subunit (LSU) of the ribosomal DNA have been sequenced and deposited at GenBank with the accession number KT722621 (ITS) and KT722622 (LSU). DNA extraction was performed with the EZ-10 Spin Column Genomic DNA Minipreps Kit, Plant (Bio Basic Canada Inc., Markham, Ontario, Canada). The Precellys 24 Homogenizer (Bertin Technologies) was used for cell disruption at a speed of $6000 \mathrm{rpm}$ for $2 \mathrm{x} 40 \mathrm{~s}$. The gene regions were amplified according to the previous descriptions. ${ }^{S 1}$

According to the BLAST search results of the submitted sequences the fungal culture is closely related to the species Laxitextum bicolor. The macro and micro morphological characteristics confirmed the relationship to the genus Laxitextum. The measured spores were broadly ellipsoid and 3,5- $4 \mu \mathrm{m} \times 5-5,5 \mu \mathrm{m}$ in size, the basidiome have a white hymenium and were measured to be up to $3,6 \mathrm{~cm}$ long in dried stage (Figure S1). Based on these characteristics the fungal specimen STMA14285 could be identified as L. incrustatum. ${ }^{\mathrm{S} 2}$ 

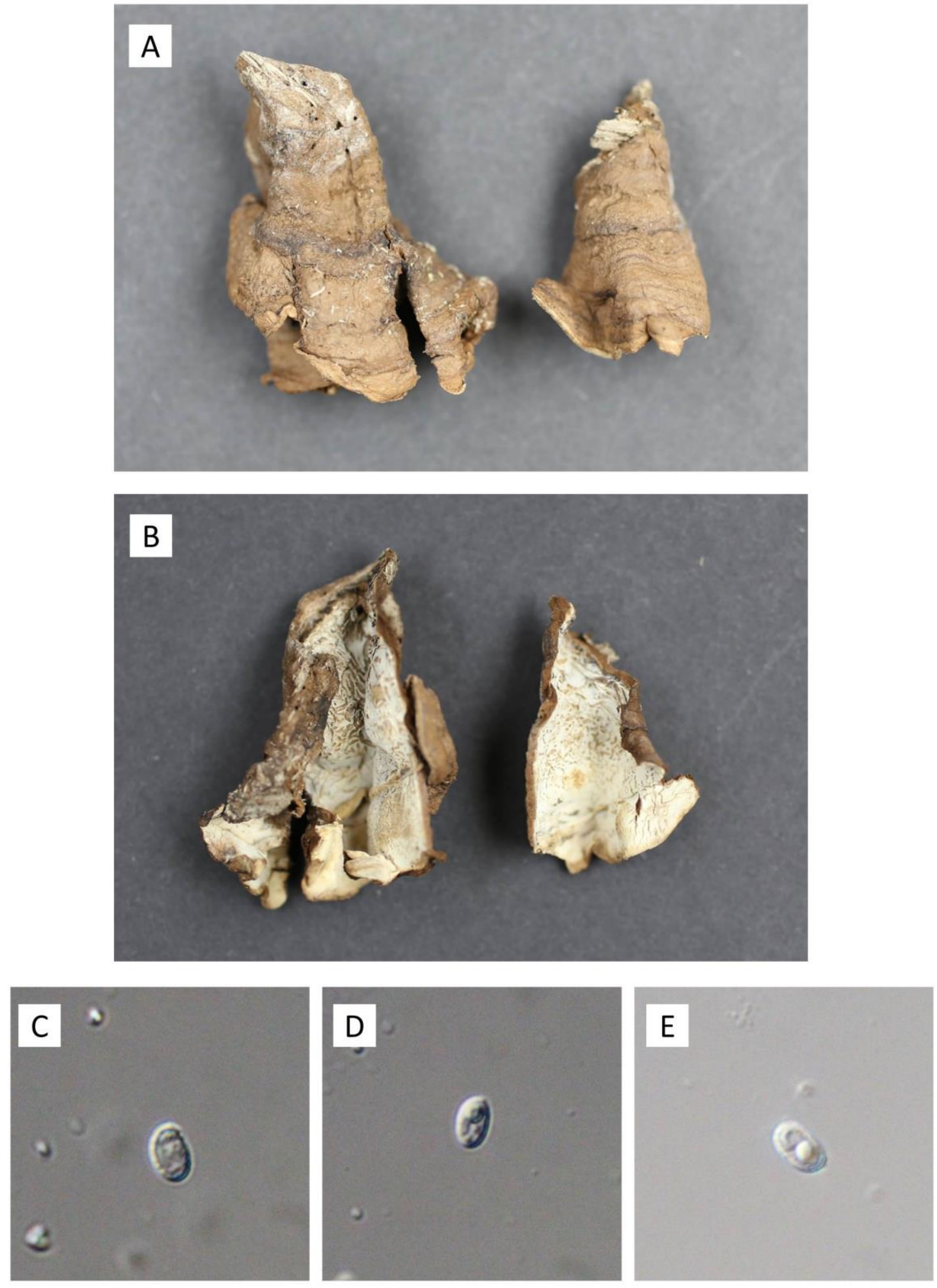

Figure S1. Macro and micro morphologic features of Laxitextum incrustatum (A and B) basidiomata ( $\mathrm{C}$ and $\mathrm{E})$ basidiospores. 


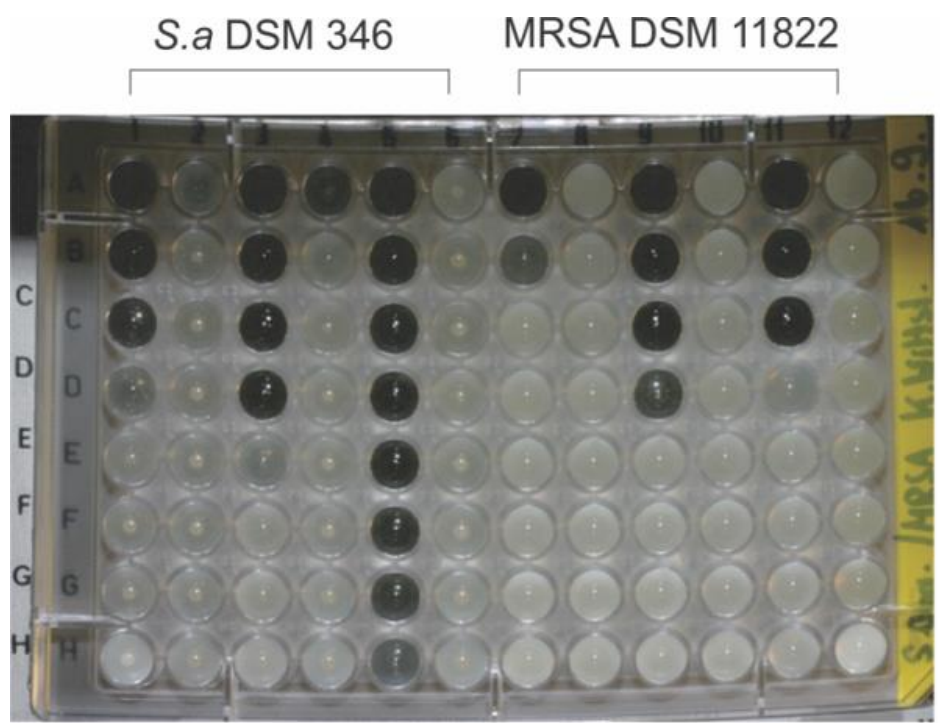

1 - Compound (2) with $20 \mu \mathrm{l}(1 \mathrm{mg} / \mathrm{ml})$

2 - Compound (2) with $2 \mu \mathrm{l}(1 \mathrm{mg} / \mathrm{ml})$

3 - Compound (1) with $20 \mu \mathrm{l}(1 \mathrm{mg} / \mathrm{ml})$

4 - Compound (1) with $2 \mu \mathrm{l}(1 \mathrm{mg} / \mathrm{ml})$

5 - Oxytetracyclin $(2 \mu \mathrm{l}$ of $1 \mathrm{mg} / \mathrm{ml})$

6 - Blank

7 - Compound (2) with $20 \mu \mathrm{l}(1 \mathrm{mg} / \mathrm{ml})$

8 - Compound (2) with $2 \mu \mathrm{l}(1 \mathrm{mg} / \mathrm{ml})$

9 - Compound (1) with $20 \mu \mathrm{l}(1 \mathrm{mg} / \mathrm{ml})$

10 - Compound (1) with $2 \mu \mathrm{l}(1 \mathrm{mg} / \mathrm{ml})$

11 - Vancomycin $(2 \mu \mathrm{l}$ of $1 \mathrm{mg} / \mathrm{ml})$

$\begin{array}{llllllllllll}1 & 2 & 3 & 4 & 5 & 6 & 7 & 8 & 9 & 10 & 11 & 12\end{array}$

Figure S2. Antimicrobial activity against Staphylococcus aureus (DSM 346) and MRSA (DSM 1182) as obtained from the serial dilution experiments (from well A to $\mathrm{H}$ ). The highest concentration in well A was $62.5 \mu \mathrm{g} / \mathrm{mL}$ when $20 \mu \mathrm{L}$ of solution was used while $6.62 \mu \mathrm{g} / \mathrm{mL}$ in the case of $2 \mu \mathrm{L}$. The dark regions indicate the inhibited wells by the test organism while the light regions show no inhibition zones. 


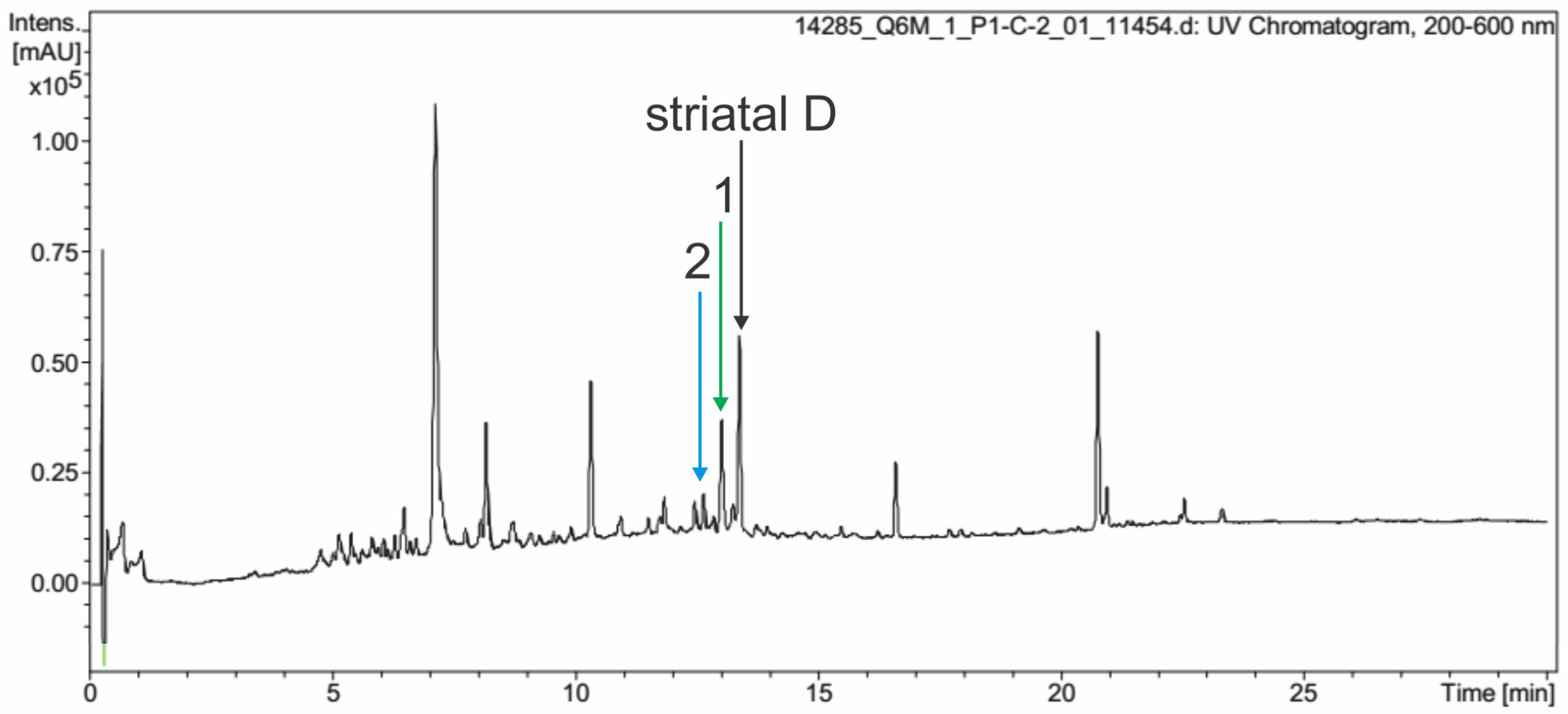

Figure S3. HPLC Chromatogram of the L. incrustatum crude extract in methanol 


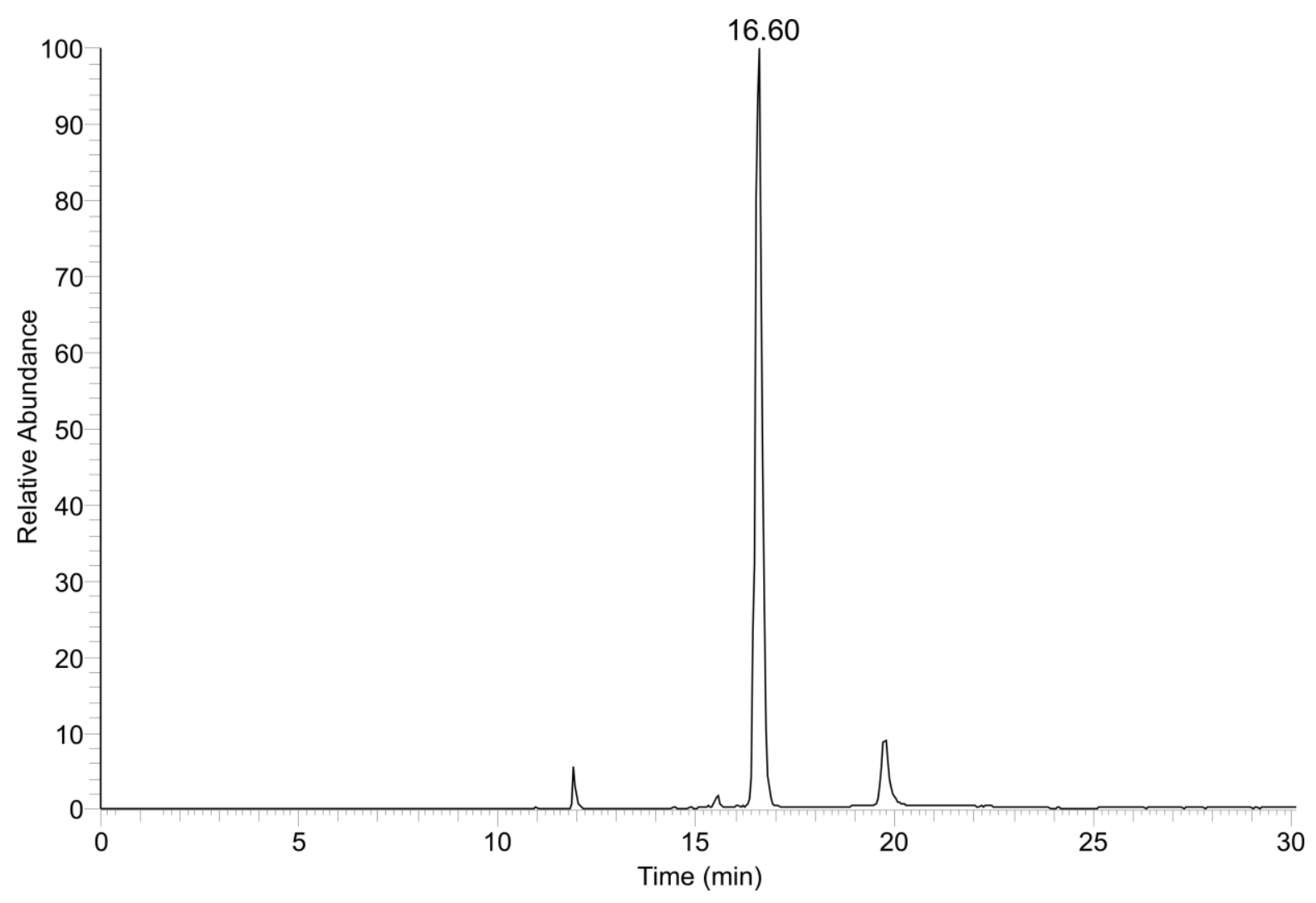

Figure S4. Total Ion Chromatogram of the purified laxitextine A (1) 


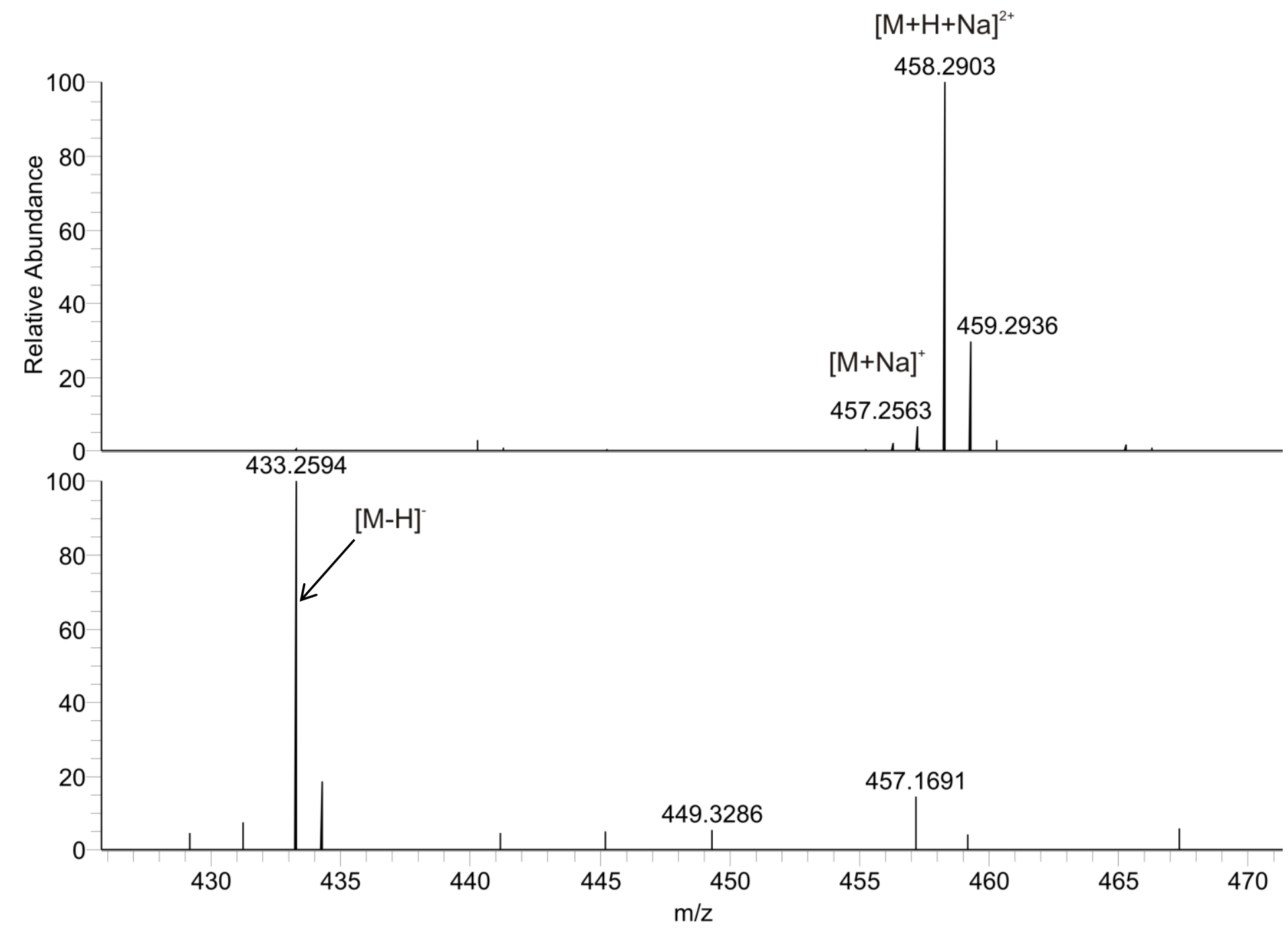

Figure S5. HR-MS mass evaluations for laxitextine A (1) 


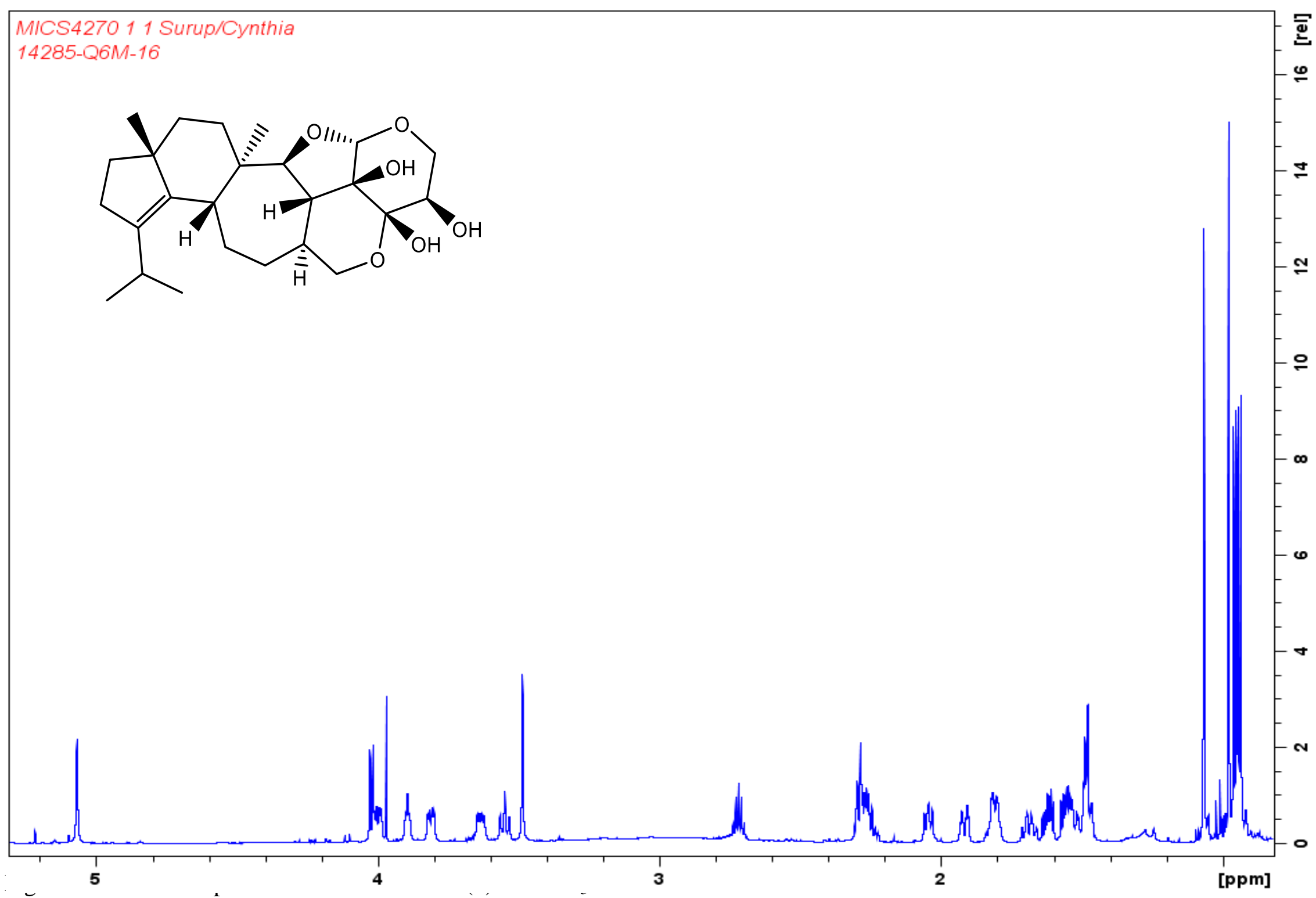




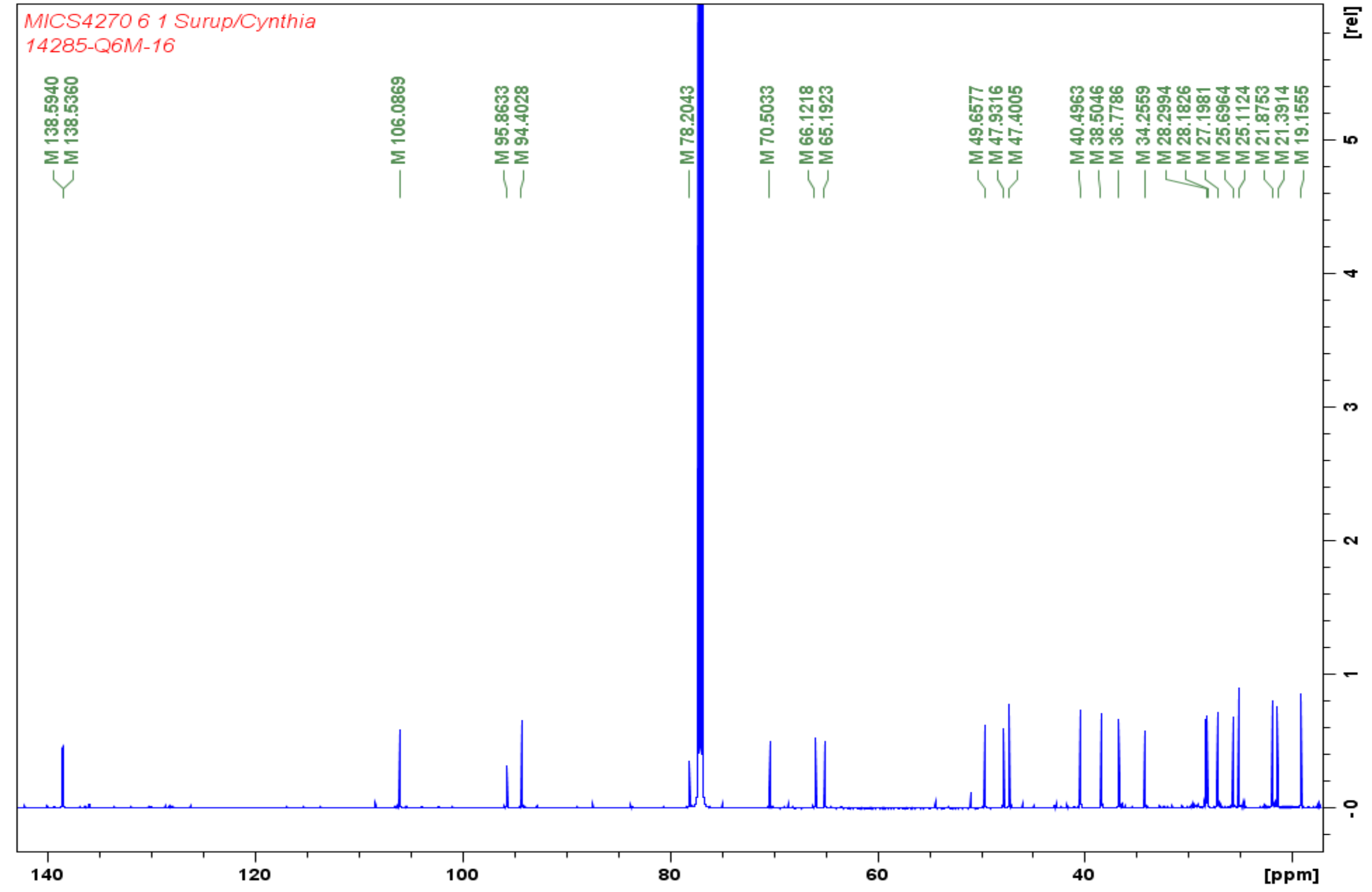

Figure S7. ${ }^{13} \mathrm{C}$ NMR spectrum for laxitextine $\mathrm{A}(\mathbf{1})$ in $\mathrm{CDCl}_{3}$ 


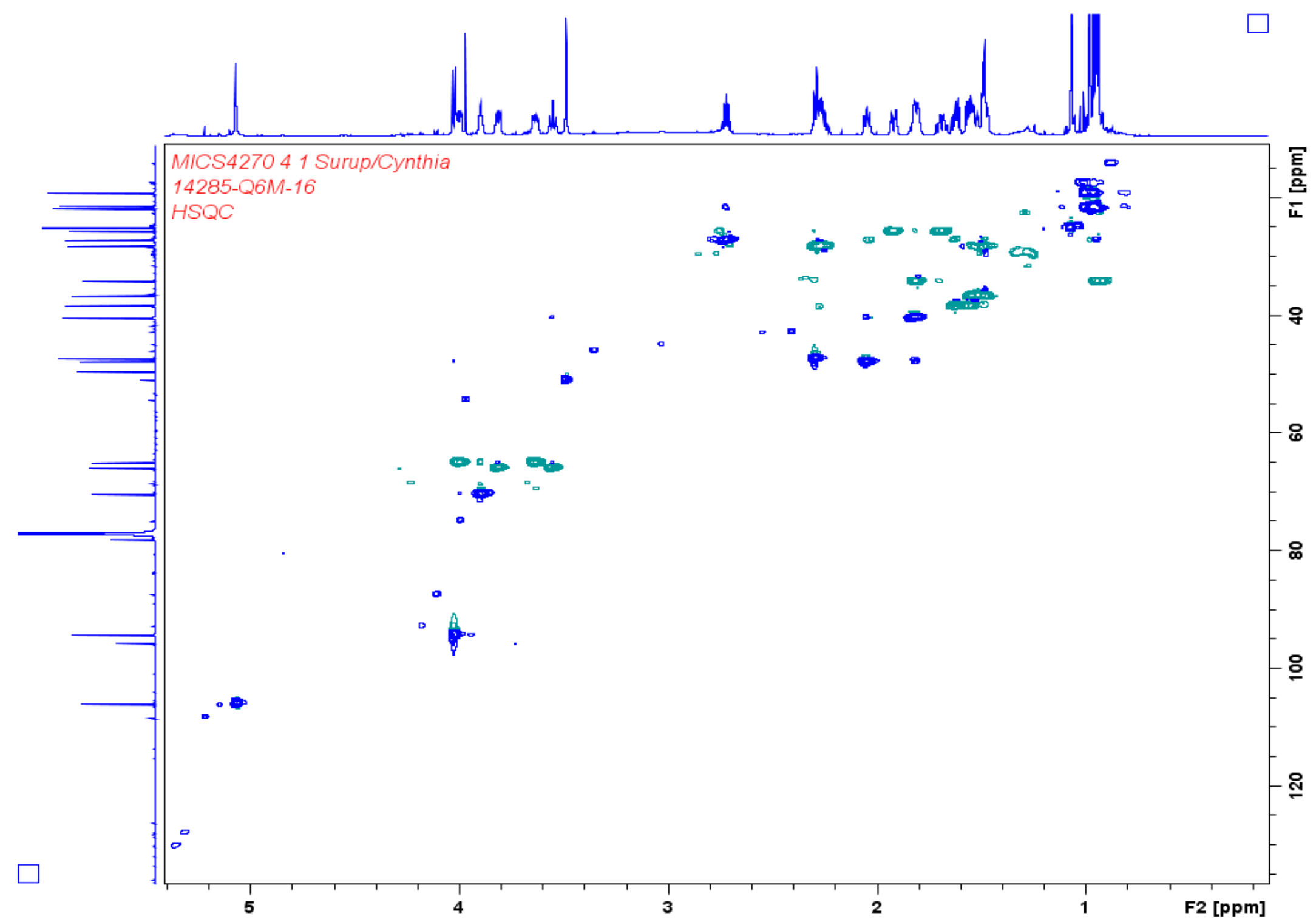

Figure S8. HSQC NMR spectrum for laxitextine $\mathrm{A}(\mathbf{1})$ in $\mathrm{CDCl}_{3}$ 


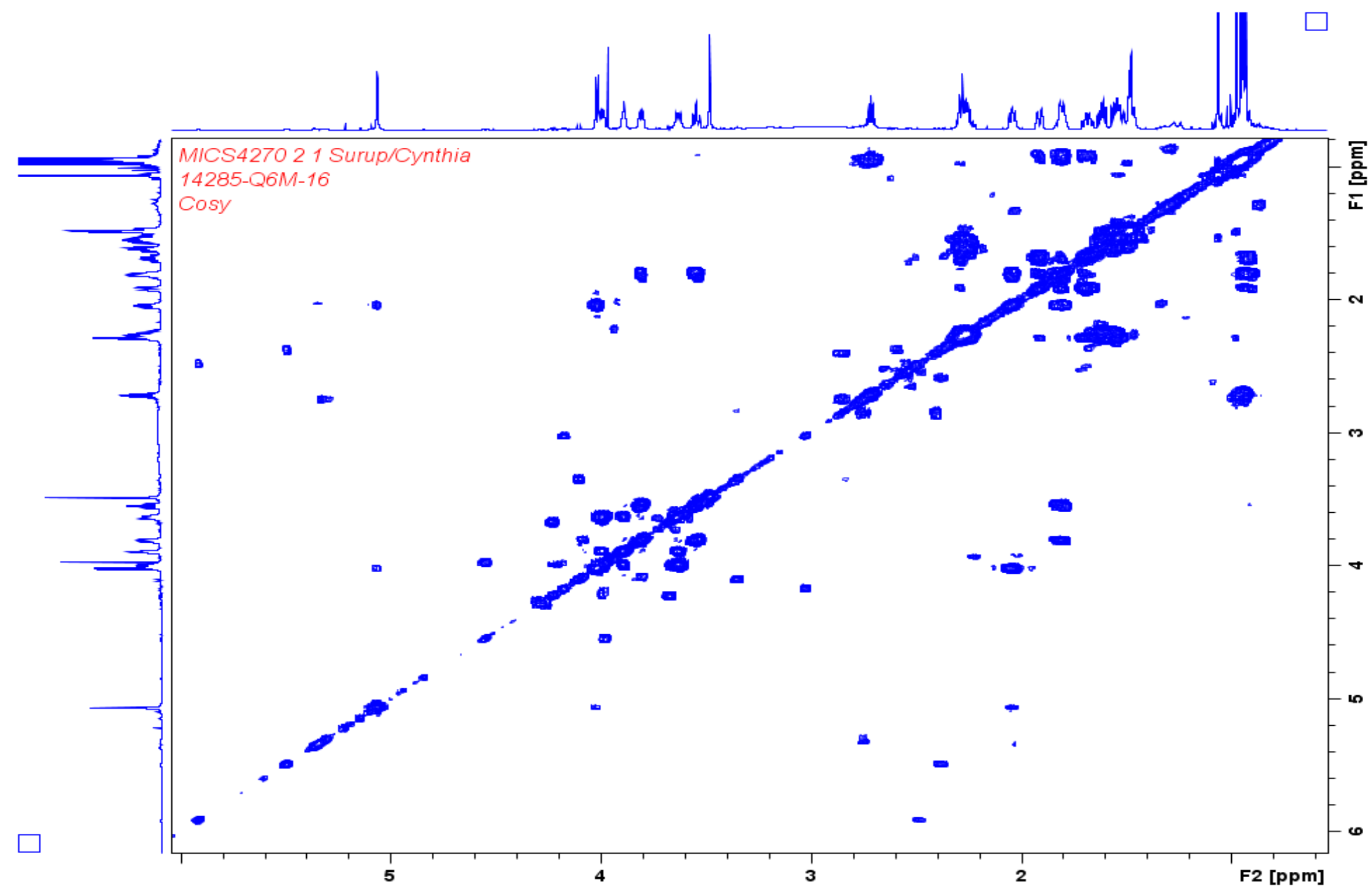

Figure S9. ${ }^{1} \mathrm{H} /{ }^{1} \mathrm{H}$ COSY NMR spectrum for laxitextine A (1) in $\mathrm{CDCl}_{3}$ 


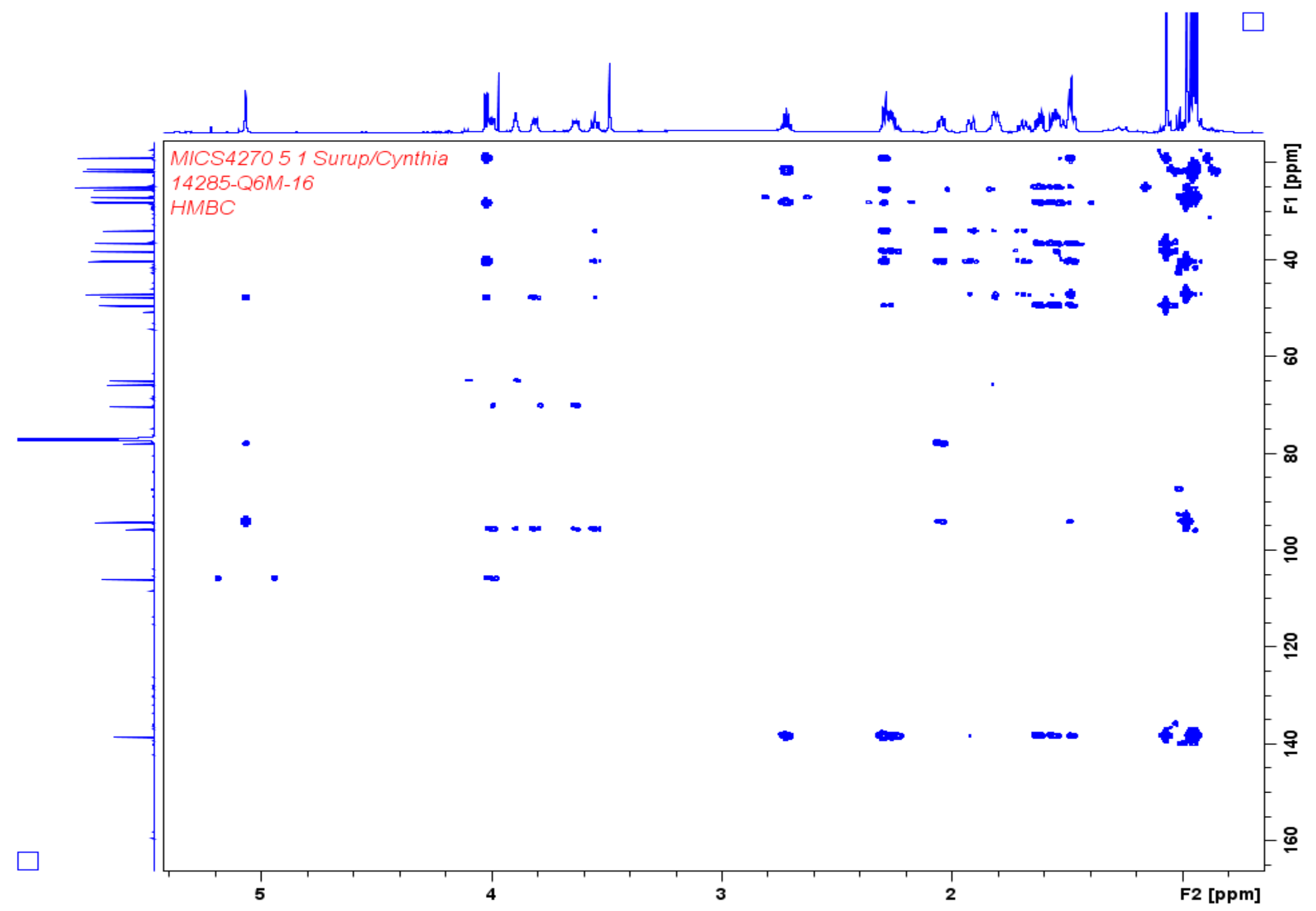

Figure S10. HMBC NMR spectrum for laxitextine $\mathrm{A}(\mathbf{1})$ in $\mathrm{CDCl}_{3}$ 


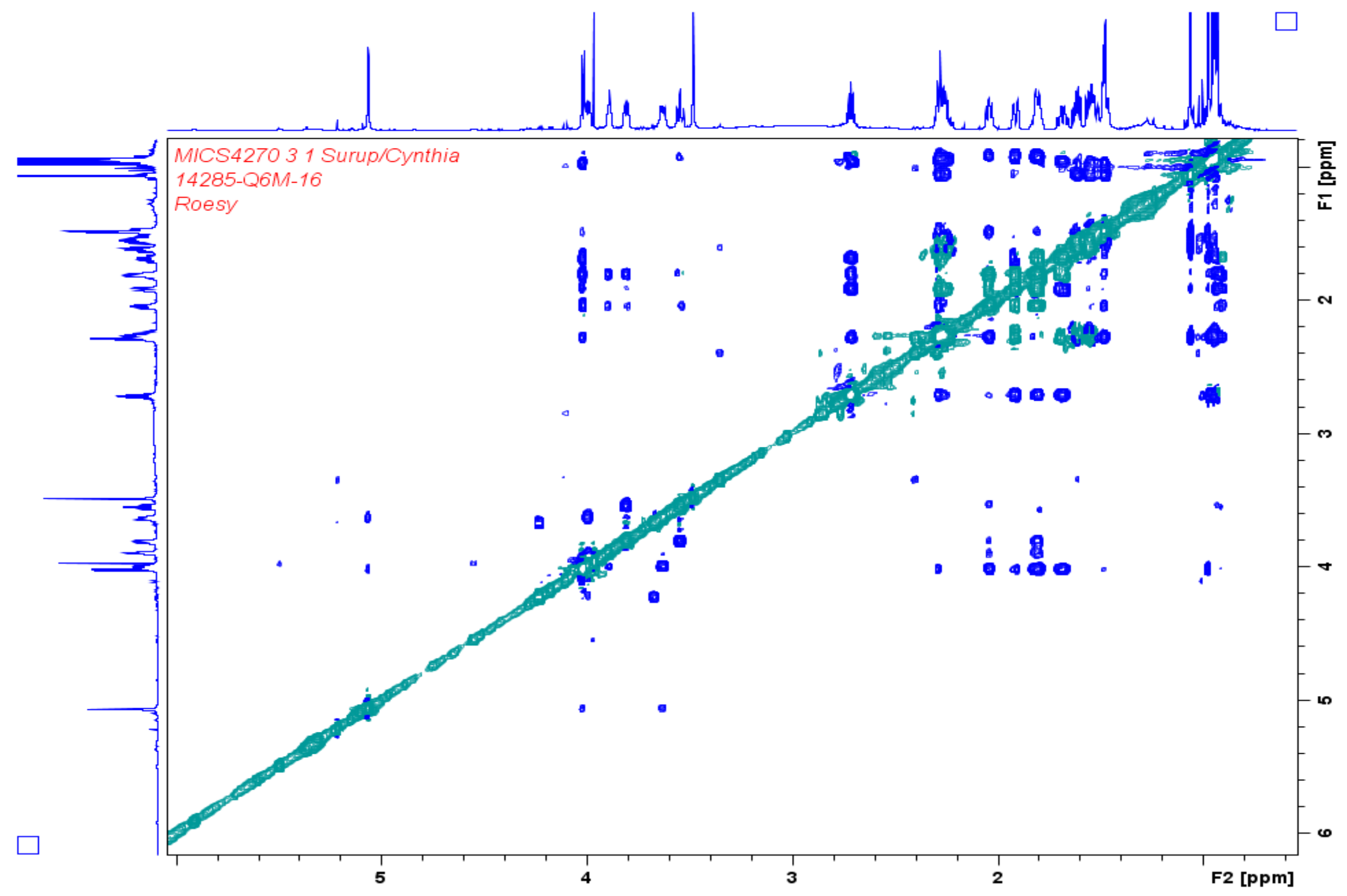

Figure S11. ROESY NMR spectrum for laxitextine A (1) in $\mathrm{CDCl}_{3}$ 


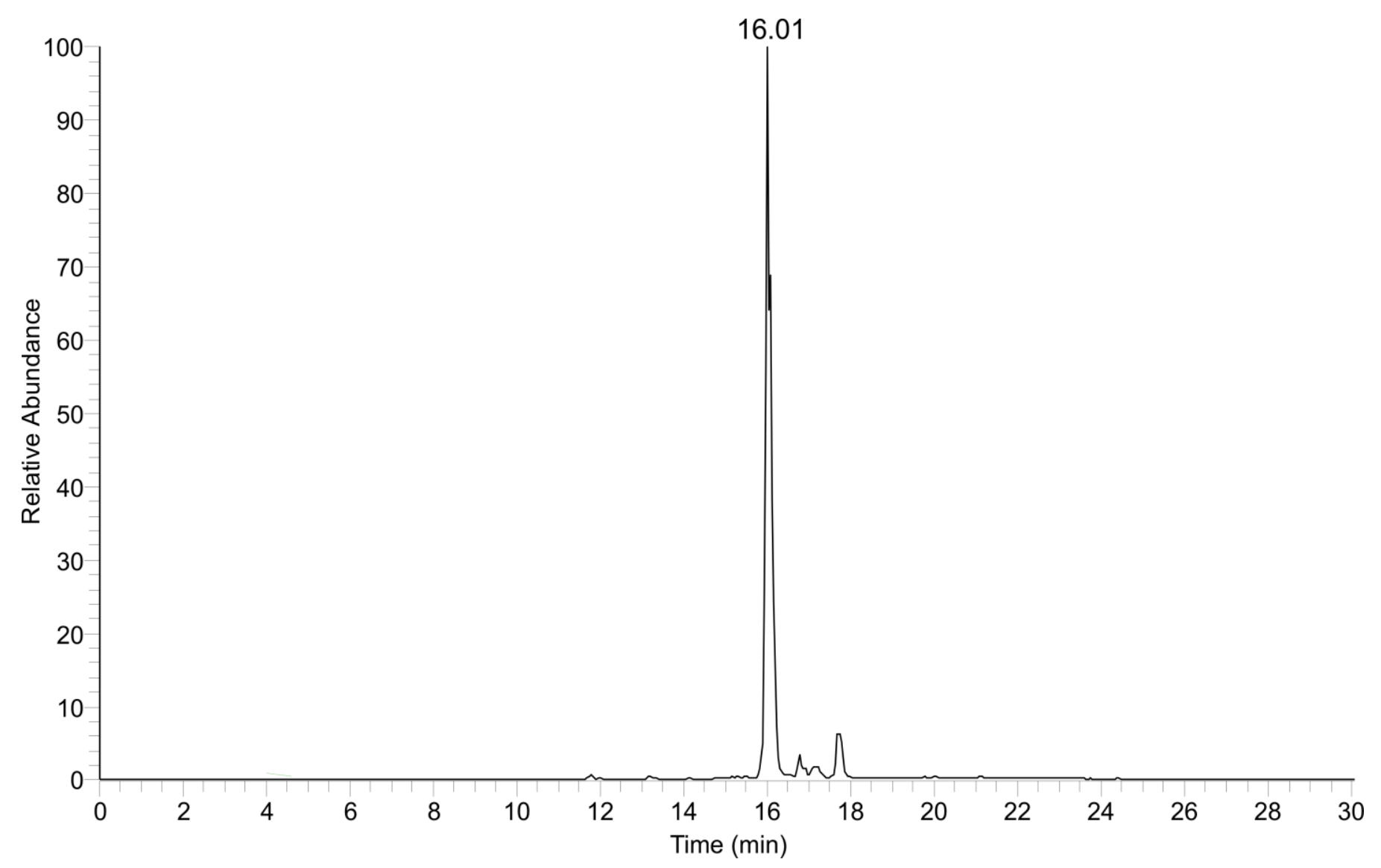

Figure S12. Total Ion Chromatogram for laxitextine B (2) 


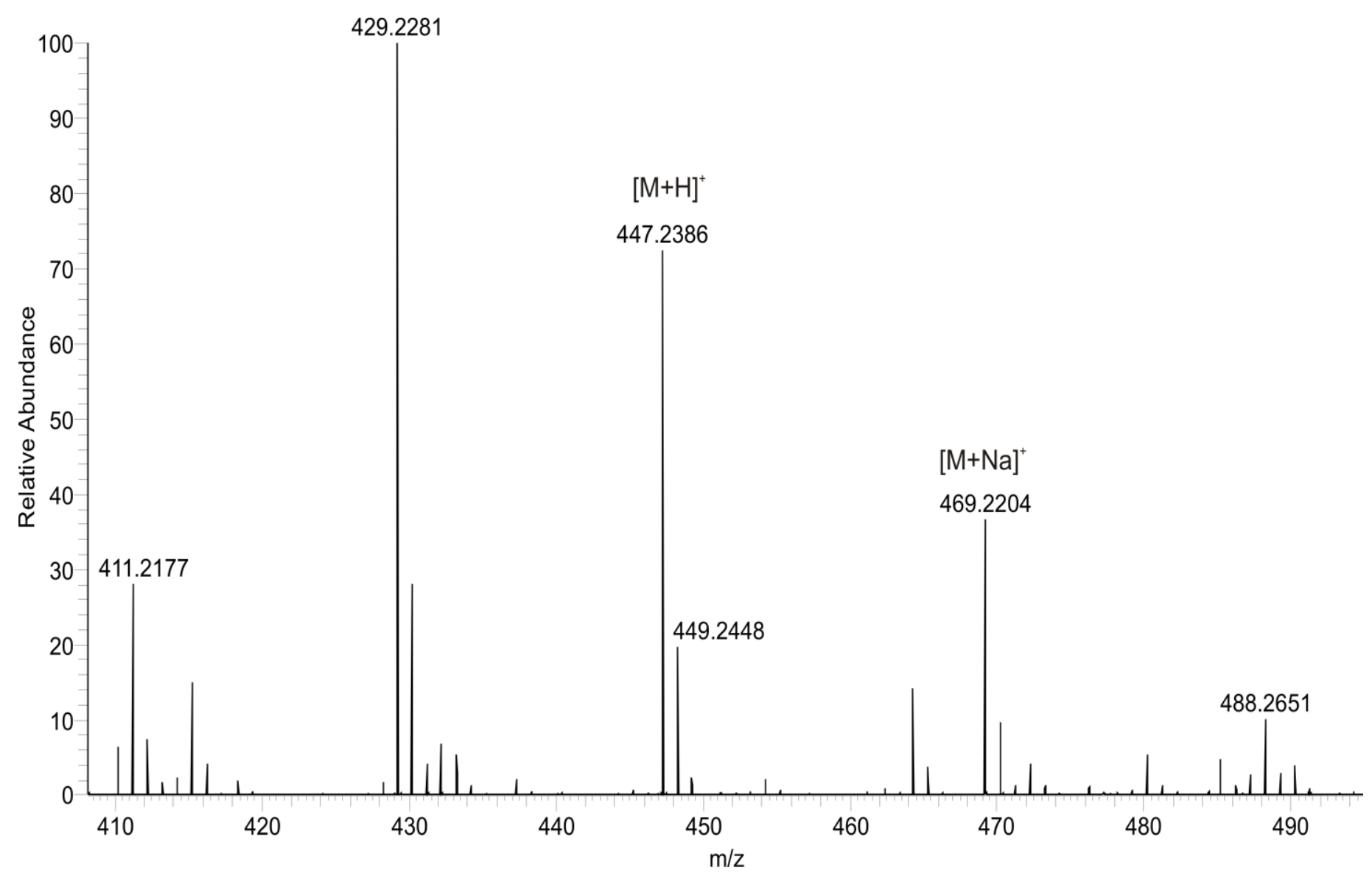

Figure S13. HR-MS for laxitextine B (2) 


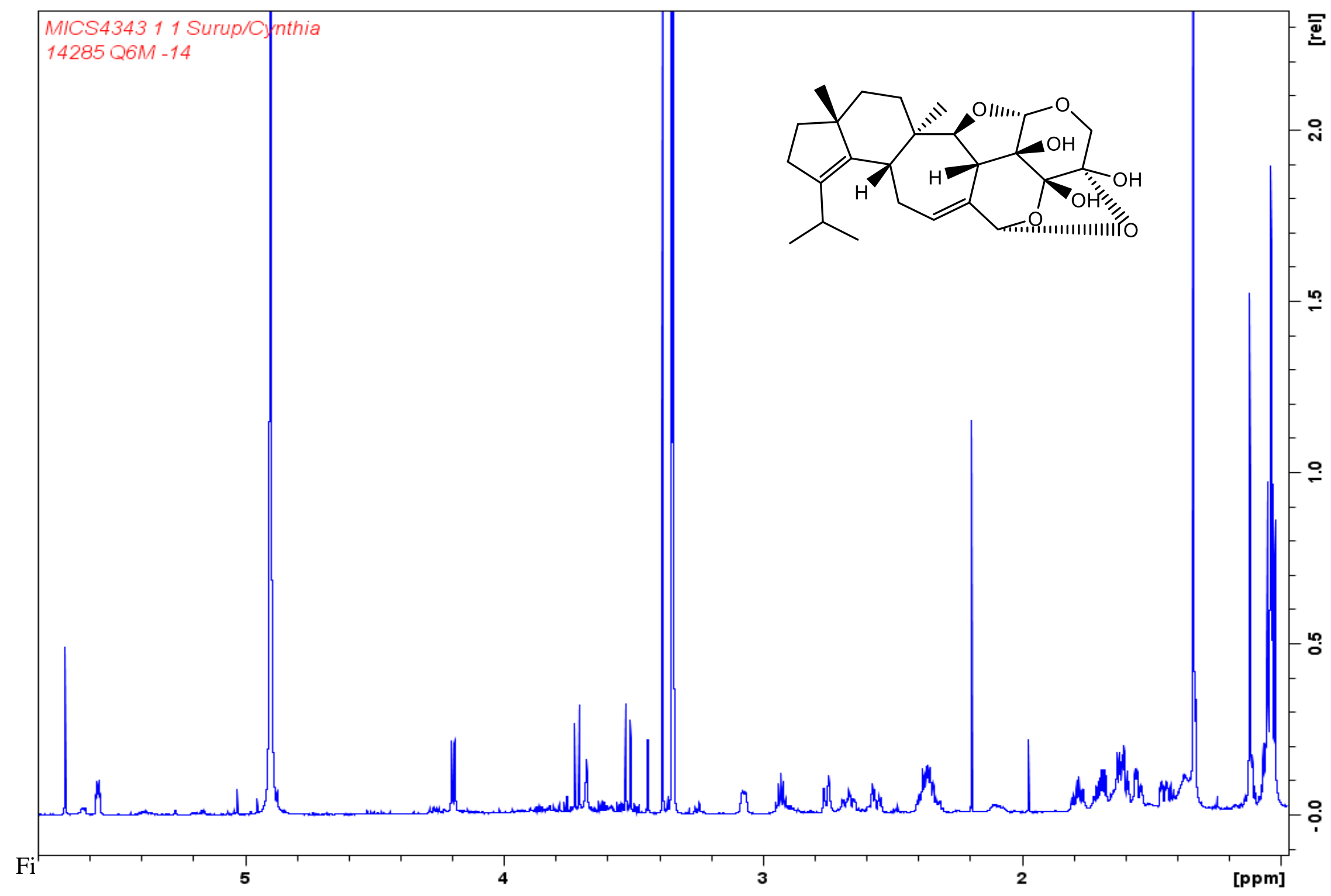




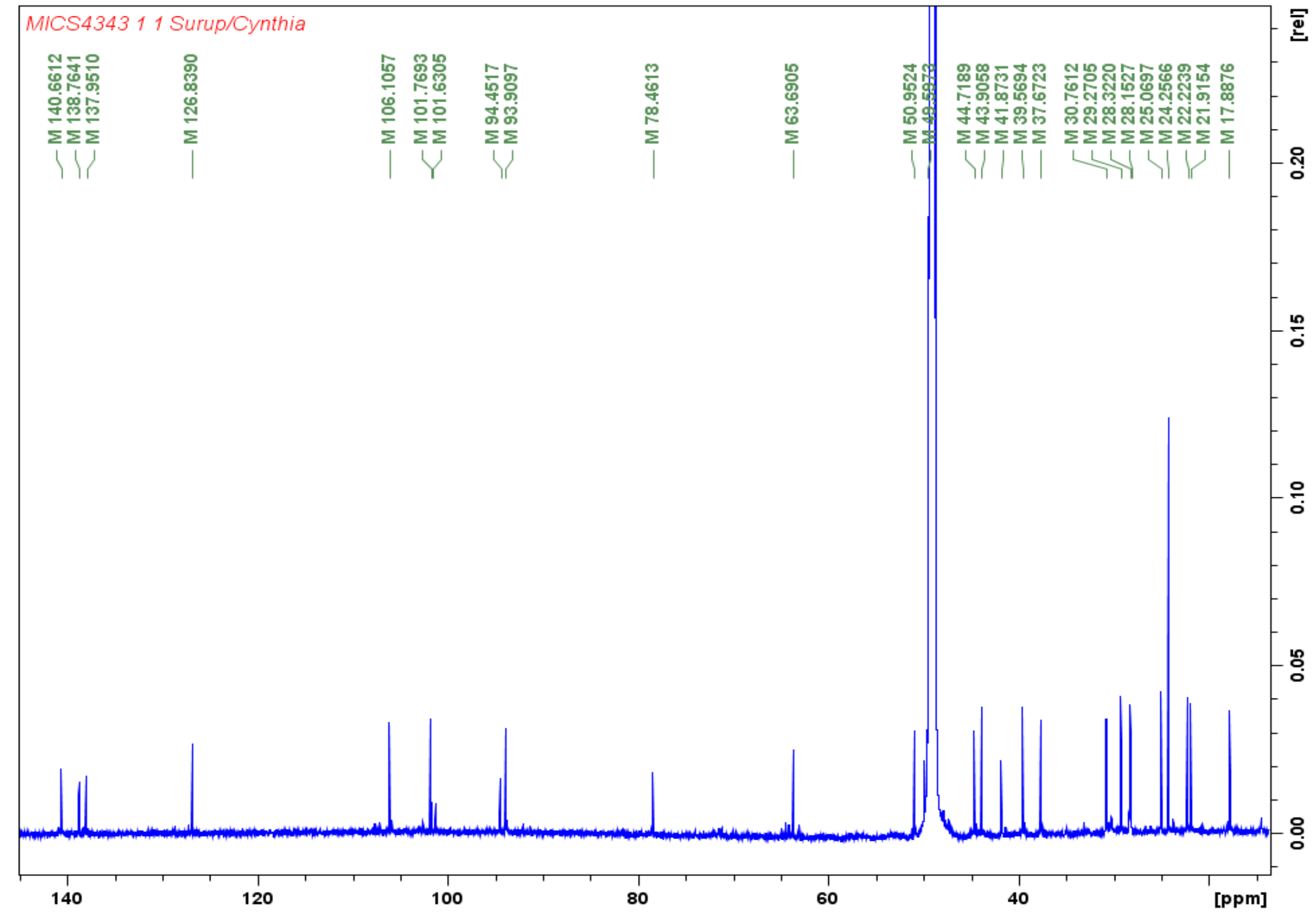

Figure $\mathrm{S} 15 .{ }^{13} \mathrm{C}$ NMR spectrum for laxitextine $\mathrm{B}(2)$ in $\mathrm{CD}_{3} \mathrm{OD}$ 


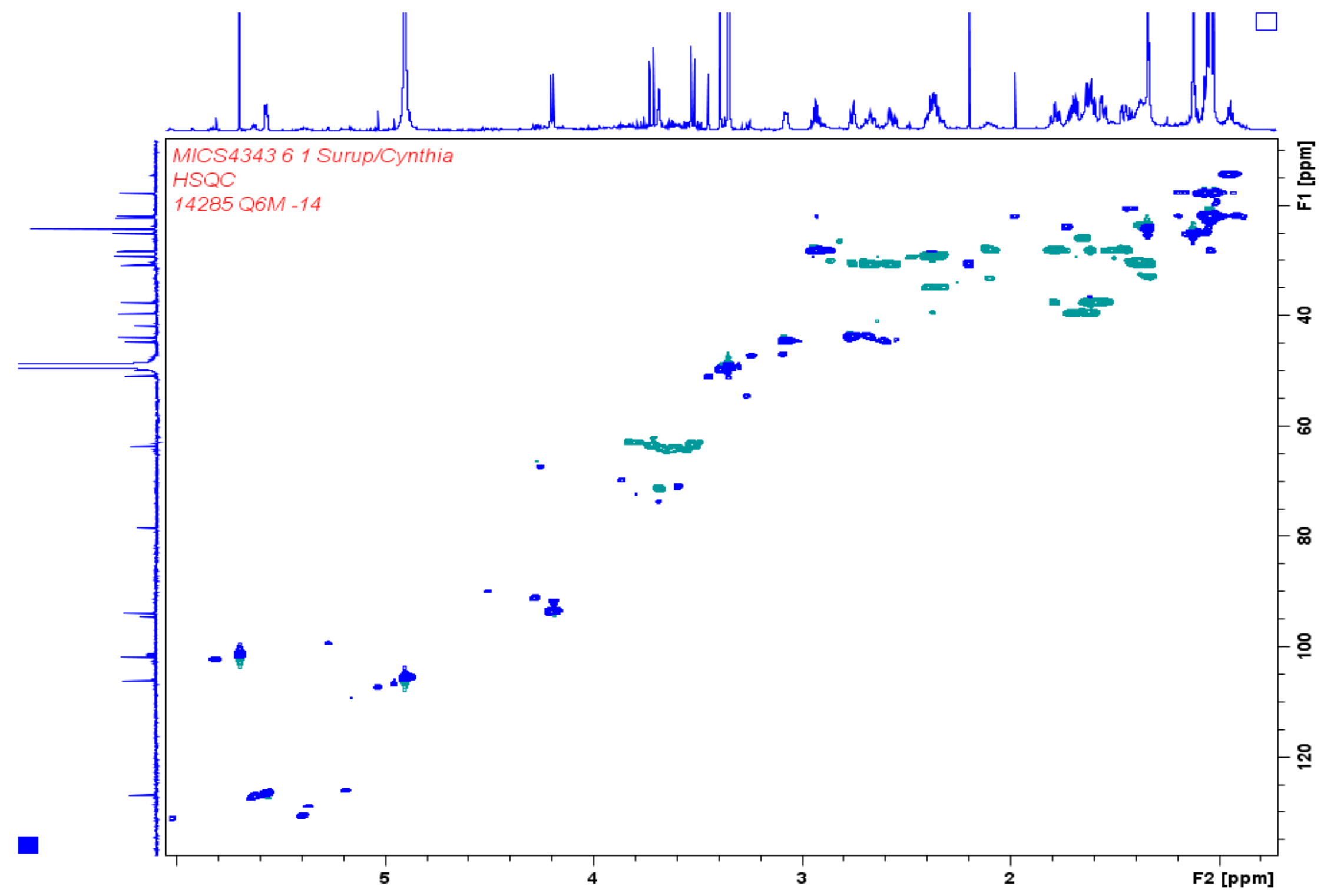

Figure S16. HSQC spectrum for laxitextine $\mathrm{B}(2)$ in $\mathrm{CD}_{3} \mathrm{OD}$ 


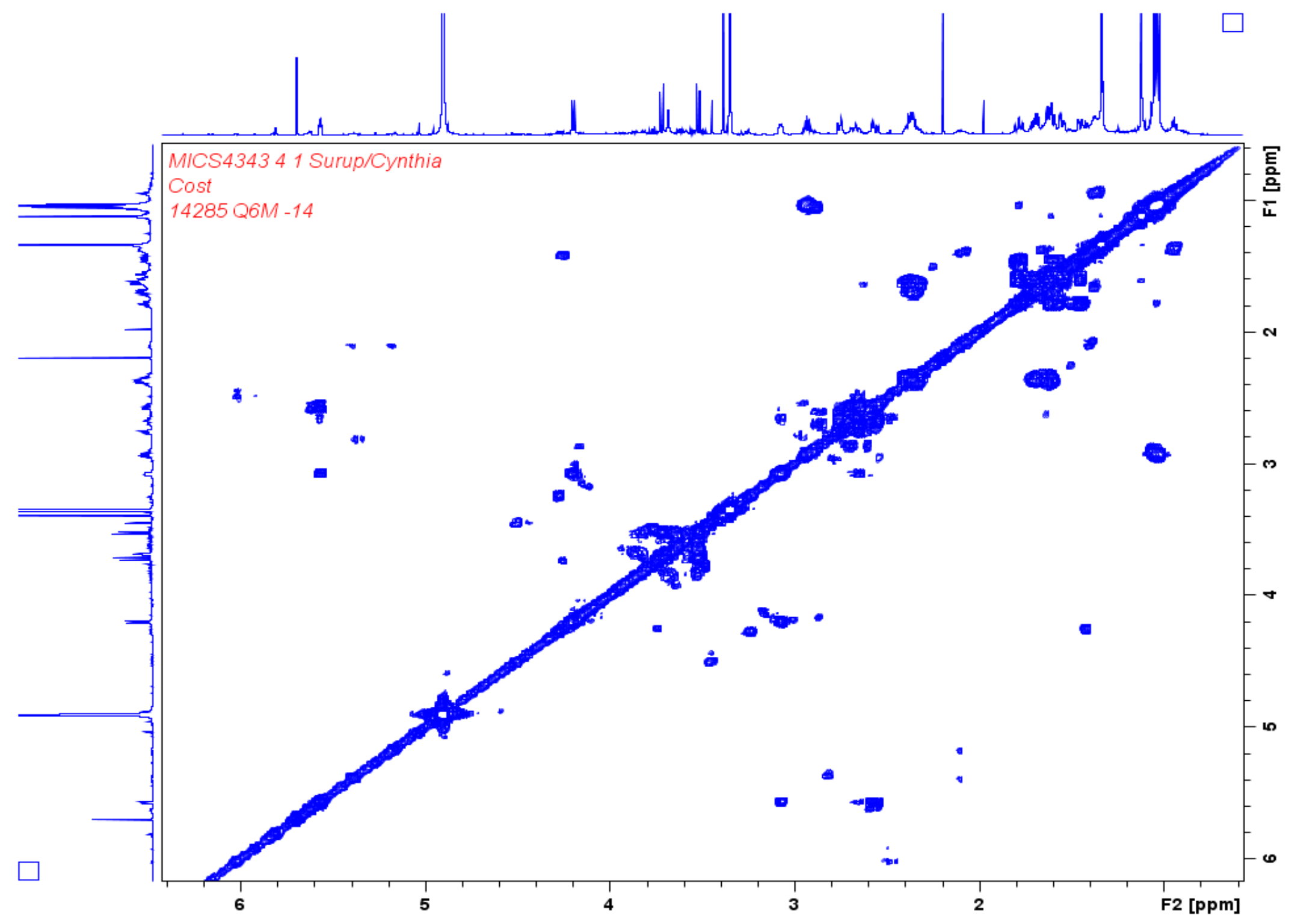

Figure S17. COSY NMR spectrum for laxitextine B (2) in $\mathrm{CD}_{3} \mathrm{OD}$ 


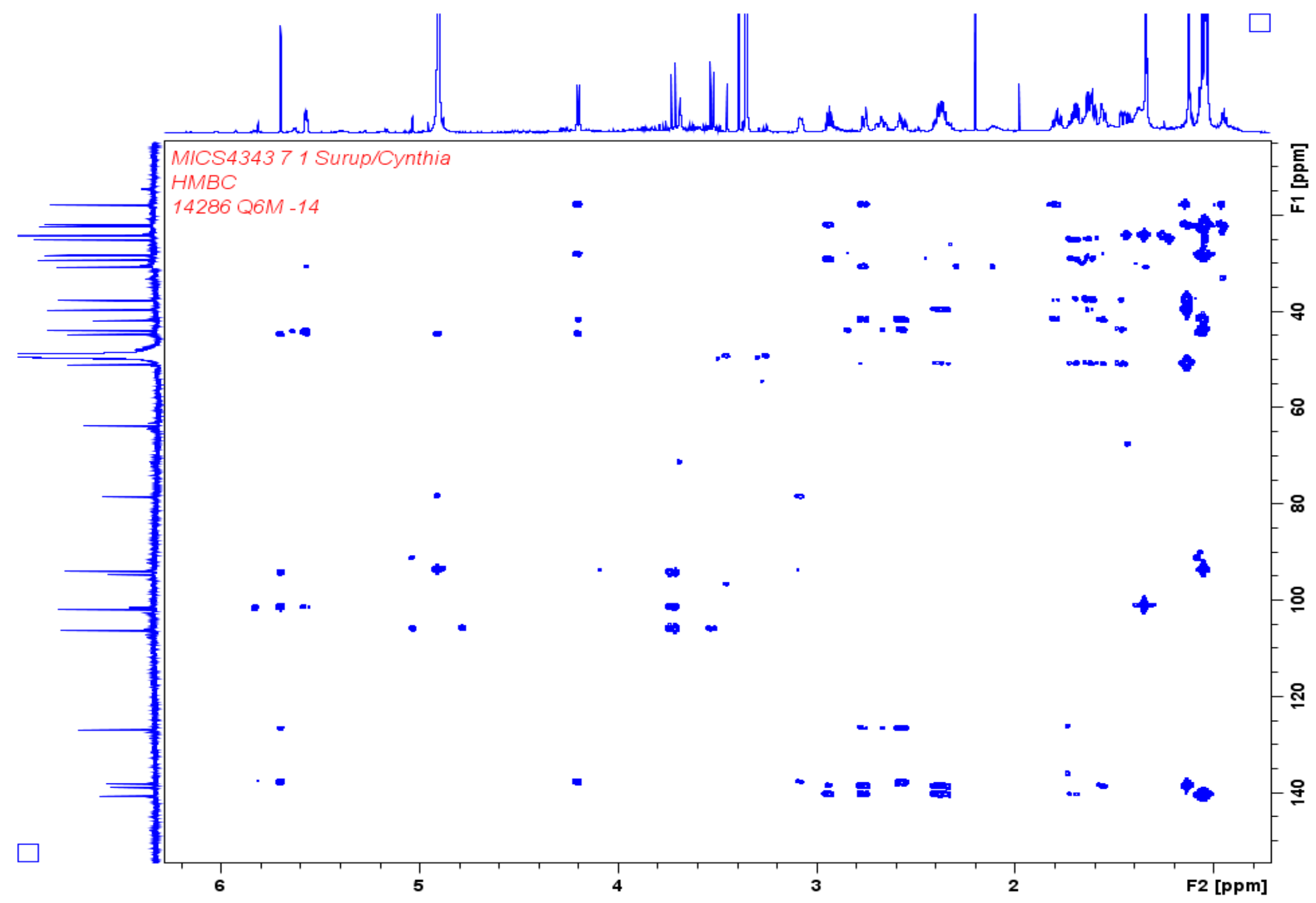

Figure S18. HMBC NMR spectrum for laxitextine B (2) in $\mathrm{CD}_{3} \mathrm{OD}$ 


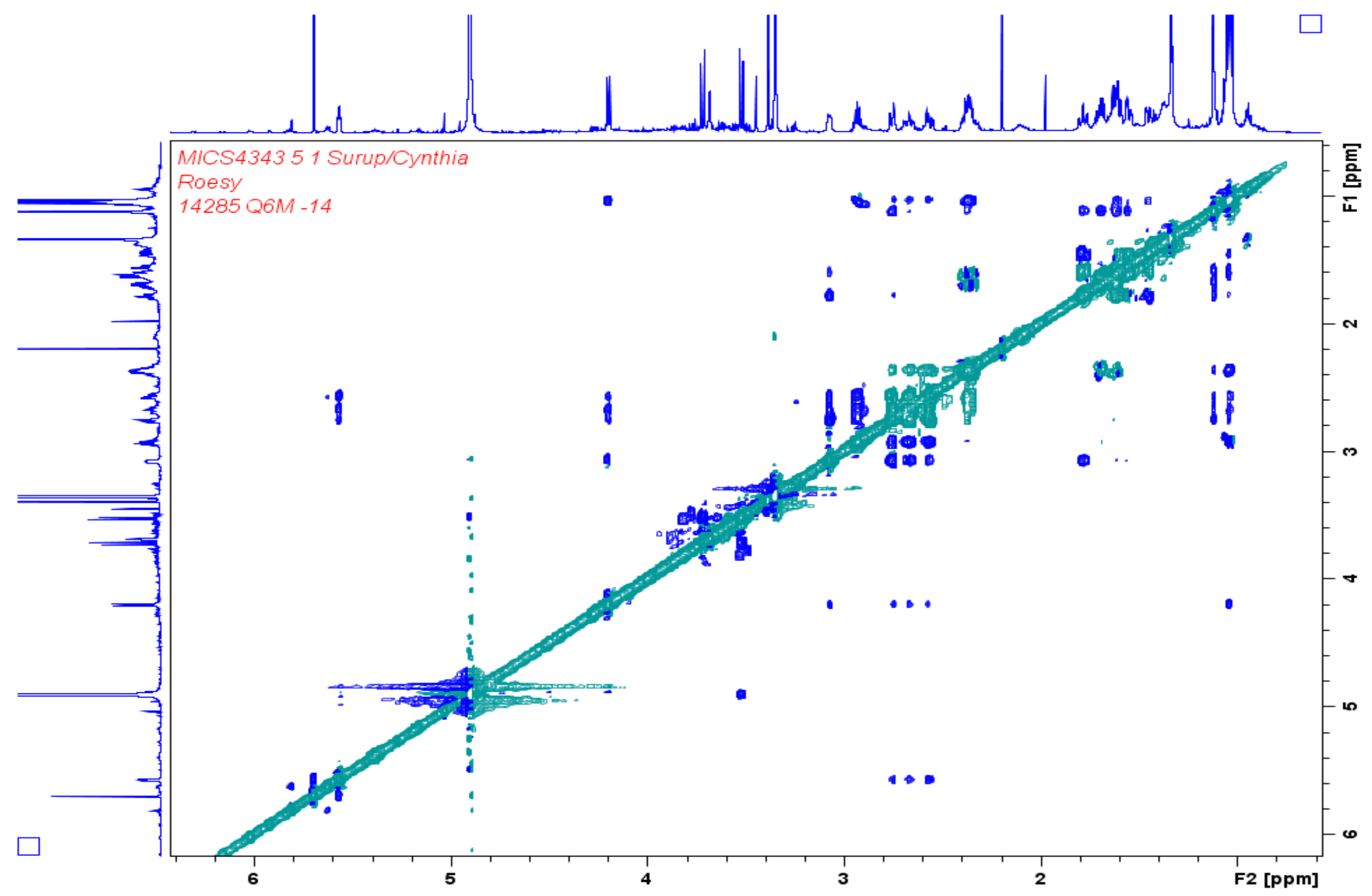

Figure S19. ROESY NMR spectrum for laxitextine $\mathrm{B}(2)$ in $\mathrm{CD}_{3} \mathrm{OD}$ 


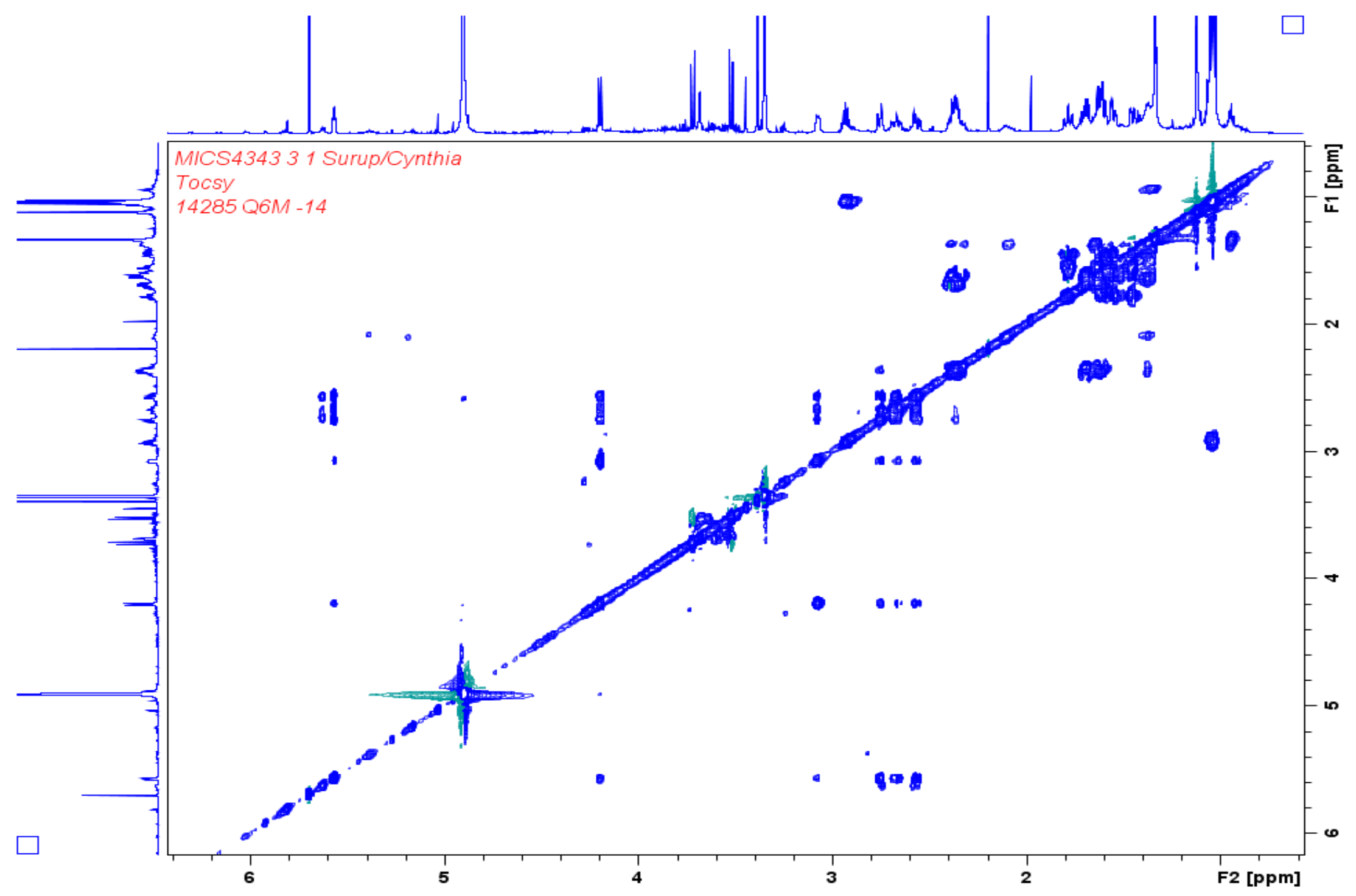

Figure S20. TOCSY NMR spectrum for laxitextine B (2) in $\mathrm{CD}_{3} \mathrm{OD}$ 


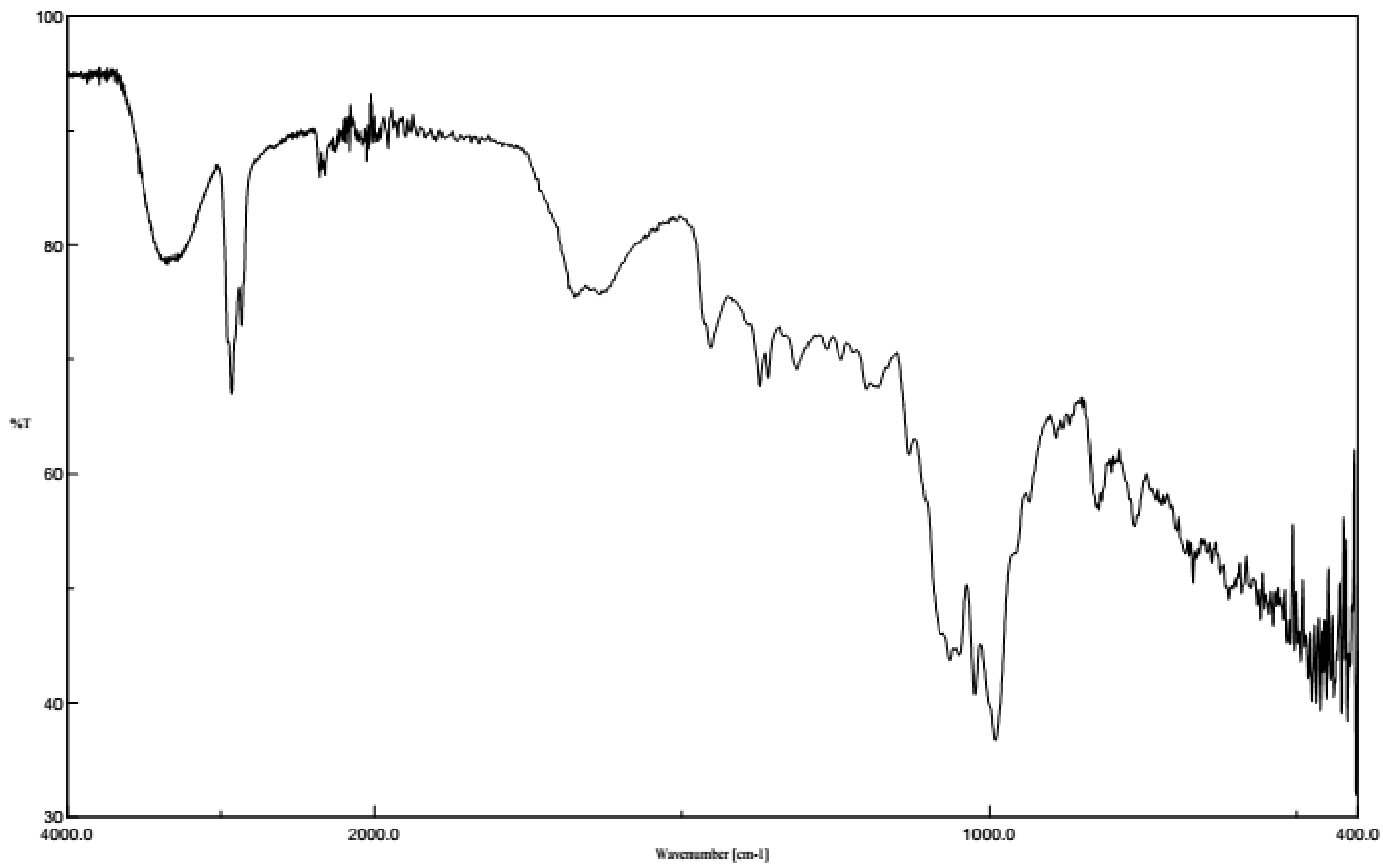

Figure S21. IR spectrum of compound 1 


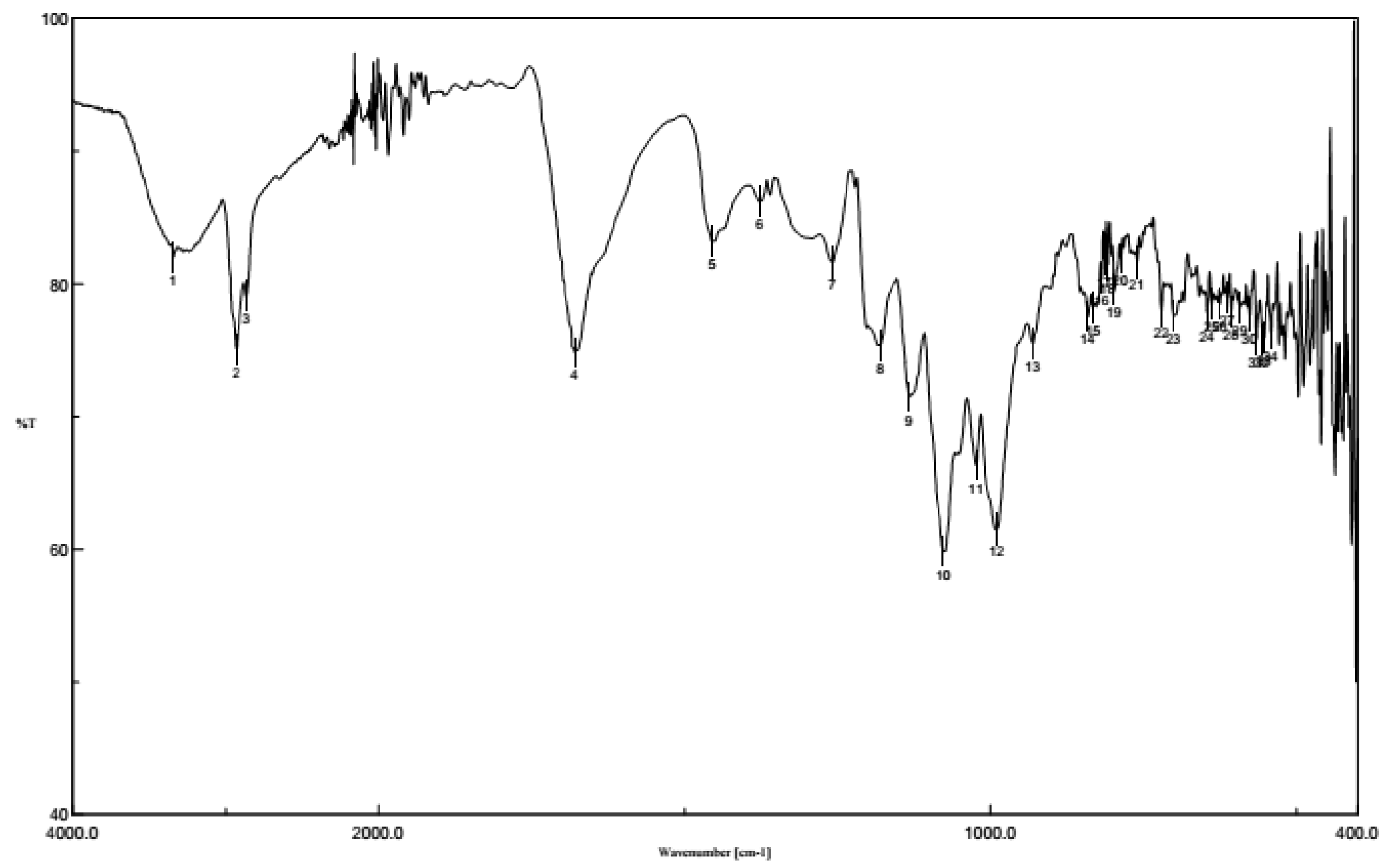

Figure S22. IR spectrum of compound 2 


\section{References}

(S1) Zhou, L. W.; Dai, Y. C. Mycologia 2013, 105, 636-649.

(S2) Hjortstam, K.; Ryvarden, L. Mycotaxon 1981, 13, 35-40 